\title{
Gambaran Sosial Ekonomi Masyarakat Pesisir di Sulawesi Selatan (Fieldwork)
}

\section{Andi Agus *1, Masayuki Yanagisawa ${ }^{2}$, Taniguchi Yukiko³ ${ }^{3}$ Hashiya Hrosyi ${ }^{4}$, Tobita Chizuru$^{5}$, Kato Kumiko 6}

\author{
${ }^{1}$ Faculty of Fisheries and Marine Science, Khairun University, Ternate, North Moluccas, Indonesia \\ 2 Center for Integrated Area Studies (CIAS), Kyoto University, Kyoto, Japan \\ ${ }^{3}$ Graduate School of Political Science, Waseda University, Tokyo, Japan \\ 4 Tokyo University of Economic \\ ${ }^{5}$ Architecture, JICA \\ ${ }^{6}$ Graduate School of Global Studies, Sophia University, Tokyo, Japan \\ *Corresponding Author: andi.agus3@gmail.com \\ Manuscript received: 20-03-2018 Revision accepted: 05-05-2018
}

\begin{abstract}
Abstrak
Penelitian ini bertujuan untuk mengamati gambaran kehidupan sosial ekonomi masyarakat pesisir di Kota Makassar, Daerah Galesong di Kabupaten Gowa dan Takalar serta Bira, Tana Beru dan Kajang, Kabupaten Bulukumba. Metode penelitian yang dipakai dalam penelitian ini merupakan metode penelitian deskriptif dengan melakukan kunjungan lapangan (field work) dan wawancara. Benteng Somba Opu adalah peninggalan sejarah Kerajaan Gowa-Tallo di Kabupaten Gowa dan Benteng Fort Rotterdam atau Ujung Pandang sering juga disebut Benteng Pannyua berada di Kota Makassar, sementara di Balla Lompoa masih bisa ditemui benda-benda peninggalan sejarah atau pusaka Kerajaan ini zaman dulu. Galesong adalah daerah yang secara administrasi tergabung dalam Kabupaten Gowa dan Takalar, penduduknya bermata pencaharian petani dan nelayan dan menjadi salah satu penyuplai bahan pangan di Kota Makassar dari jaman dulu sampai sekarang serta menggunakan bahasa Makassar dalam berkomunikasi sehari-hari. Penduduk Bira, Ara dan Tana Baru serta Kajang menggunakan Bahasa Konjo, sub bahasa dari Makassar dengan pekerjaan utama melaut dan membuat serta melayarkan perahu pada penduduk Bira, Ara dan Tana Beru. Penduduk Kajang terdiri dari Kajang Dalam dan Luar dimana Kajang dalam masih mempertahankan aturan adat yang diketuai oleh Ammatoa dibantu oleh beberapa tetua adat dengan bekerja sesuai dengan aturan adat, sementara Kajang Luar sudah beradaptasi dengan perubahan. Umumnya pekerjaan masyarakat sebagai Petani dan Nelayan.
\end{abstract}

Kata Kunci: Ammatoa, Gowa-Tallo, Kajang, Makassar, Sosial Ekonomi

\begin{abstract}
The purpose of this research are to observe description of social economic of coastal community in Makassar Manucipality, Galesong Region in Gowa District and Takalar District and also Bira,
\end{abstract}




\section{TECHNO: Vol. 07 ( 01) Mei 2018}

Tana Beru and Kajang in Bulukumba District. Research method using at this research is research method description with collecting data through fieldwork and interviews. Somba Opu Bastiong is inheritancing history of Gowa-Tallo Empire at the Gowa District while Fort Rotterdam or Ujung Pandang and also called Pannyua Bastiong is locating at Makassar Manucipality. Balla Lompoa or called Home Bigger is found history inheritance of this empower since several centuries ago. Galesong is region as an administrative including to Gowa District and Takalar district which its inhabitants are working as a farmer and fishermen whom they are supplying food to Makassar from former times to present and using Makassarese to communicate daily. Bira, Ara, Tana Beru and also Kajang use Konjo, sub language of Makassarese to communicate as a working go to the see and building or shilling ship. Kajang inhabitants consisted of in-Kajang and off-Kajang whom In-Kajang was still using custom and traditions rules of it who leader an ammatoa namely. He assisted several the oldest person customs and traditions who worked according its rules while off-Kajang have been changing of adaptation. They worked as a farmer and fishermen generally.

Keywords: Ammatoa, Gowa-Tallo, Kajang, Makassar, Social Economy

\section{PENDAHULUAN}

Indonesia adalah negara kepulauan yang terdiri atas kurang lebih 17.000 buah pulau besar dan kecil. Beberapa pulau tersebut belum mempunyai nama dan berpenghuni. Indonesia terdiri dari 5 buah pulau besar seperti Sumatera, Kalimantan, Jawa, Sulawesi dan Papua, ditambah pula dengan ribuan pulau-pulau kecil yang tersebar dari Sabang sampai Merauke. Selain itu Indonesia mempunyai garis pantai terpanjang di dunia yaitu kurang lebih 81.000 km. Kepulauan Indonesia yang dua pertiganya adalah laut, di dalamnya terkandung kekayaan keanekaragaman hayati yang tersebar mulai dari dasar laut sampai daerah permukaan. Hal ini yang menyebabkan sebagian besar penduduknya tinggal di daerah pesisir dan mengeksploitasi sumberdaya pesisir untuk memenuhi kebutuhannya (Nuitja, 2010).

Provinsi Sulawesi Selatan adalah provinsi yang terdapat di Pulau Sulawesi bagian selatan. Provinsi ini berbatasan dengan Sulawesi Tengah di sebelah utara, sebelah timur dengan Teluk Bone dan Sulawesi Tenggara, sebelah barat berbatasan dengan Selat Makassar dan Sulawesi Barat, serta sebelah selatan dengan Laut Flores. Bentuk topografi darat provinsi ini terdiri atas dataran rendah yang luas pada sebelah timur, selatan dan barat, sementara pada bagian tengah terdiri atas dataran rendah yang tidak terlalu luas, ke utara terdiri atas dataran tinggi yang sebagian berbentuk hamparan yang tidak terlalu luas dan berbukit-bukit.

Dataran rendah di sebelah barat sebagian besar terdiri atas areal pertanian seperti sawah dan perkebunan, sebagian kecil merupakan lahan untuk perikanan seperti tambak. Lahan pertanian sebagian besar terdapat di Kabupaten Maros, Pangkep, Pinrang dan sebagian kecil di Kabupaten Barru, sementara lahan tambak sebagian besar terdapat di Kabupaten Pangkep dan Pinrang. Daerah-daerah pesisir pada kawasan ini menjadi penghasil sumber daya perikanan terutama pesisir Kota Makassar, Maros, Pangkep, Barru, Pare-Pare dan Pinrang. 
Di sebelah selatan, dataran rendahnya membujur mulai dari Kabupaten Gowa, Takalar, Jeneponto, Bantaeng dan Bulukumba. Daerah-dearah yang menjadi sentra penghasil pertanian terdapat di kawasan ini adalah kabupaten Gowa, Takalar, Bantaeng, Jeneponto dan kabupaten Bulukumba.

Pada bagian sebelah timur, sebagian besar merupakan lahan pertanian terdiri persawahan yang membujur mulai dari kabupaten Sinjai, Bone, Wajo, Luwu dan Luwu Utara. Daerah-daerah pegunungan yang membujur pada bagian tengah merupakan penghasil perkebunan mulai dari Malino, kabupaten Gowa dan Sampeang, Tanete dan Kajang, kabupaten Bulukumba serta Sinjai bagian selatan. Daerah-daerah ini penghasil buah-buahan untuk daerah Malino dan sekitarnya di kabupaten Gowa, penghasil sayuran di kabupaten Jeneponto dan Bantaeng, penghasil cengkeh, merica, karet dan jenis perkebunan lainnya di kabupaten Bulukumba dan Sinjai. Ke arah utara, merupakan perkebunan penghasil kemiri di kabupaten Bone dan lebih ke utara lagi membentang luas pertanian berupa persawahan dan perkebunan di kabupaten Soppeng, Wajo serta Sidrap serta beberapa lahan persawahan yang tidak terlalu luas di kabupaten Enrekang dan Toraja serta Toraja Utara.

Daerah-daerah pesisir pantai timur juga merupakan penghasil perikanan dan kelautan dengan daerah penangkapan mereka di sekitar Teluk Bone. Daerah-daerah tersebut adalah sebagian nelayan di kabupaten Bulukumba, kabupaten Sinjai, Bone, Luwu, Palopo, Luwu Utara dan Timur. Sementara daerah-daerah pegunungan seperti Kabupaten Soppeng, Sidrap, Enrekang, Toraja dan Toraja Utara adalah penghasil ikan-ikan perairan darat dari danau, sungai dan saluran-saluran air di sawah dan alam.

Tujuan dari kegiatan field work ini adalah untuk mengamati kehidupan masyarakat pesisir di Kota Makassar, Daerah Galesong di Kabupaten Gowa dan Takalar serta Bira, Tana Beru dan Kajang, kabupaten Bulukumba. Penelitian ini berguna sebagai bahan informasi bagi pihak-pihak terkait, termasuk peneliti sosial dan pengambil kebijakan (eksekutif, legislatif dan yudikatif) dalam penelitian dan pembangunan terutama di wilayah-wilayah sasaran fieldwork.

\section{METODE PENELITIAN}

Metode penelitian yang dipakai dalam penelitian ini merupakan metode penelitian deskriptif dengan melakukan kunjungan lapangan (field work) dan wawancara. Pengumpulan data dilakukan terhadap masyarakat pesisir yang mendiami Kota Makassar, Daerah Galesong di kabupaten Gowa dan Takalar serta Bira, Tana Beru dan Kajang di kabupaten Bulukumba. Waktu Penelitian ini dilakukan pada tanggal 3-6 November 2017 di daerah bagian selatan Sulawesi Selatan. 


\section{HASIL DAN PEMBAHASAN}

\section{Kota Makassar}

Kota Makassar adalah kota yang dulunya menjadi pusat kerajaan Gowa-Tallo. Kota ini telah mengalami perkembangan baik dari segi luas wilayahnya maupun penduduk beserta mobilitasnya. Makassar menjadi penting di kawasan ini sejak awal abad 16 sampai menjelang berakhirnya paruh abad ke 16 dan menjadi pusat dan transit perdagangan dikawasan timur Indonesia sehingga kerajaan Gowa-Tallo menjadi kaya raya di masa pemerintahan I Manuntungi Daeng Mattola Karaeng Lakiung, Sultan Malikussaid, Raja Gowa ke 15 dan I Mallombasi Daeng Mattawang Karaeng Bonto Mangape, Sultan Hasanuddin, Raja Gowa ke-16 dengan Mangkubuminya yang pertama Mangadacinna Daeng Sitaba, kedua Karaeng Pattingaloang, dan Raja Tallo yang dijuluki Master atau Doktor tanpa gelar, dengan kemampuan intelektual yang tinggi, ahli dalam strategi bertempur dan menguasai banyak bahasa sehingga bisa berkomunikasi dan membawa hubungan dagang Gowa-Tallo dengan bangsa Eropa (Portugis, Spanyol dan Belanda yang kemudian menjajah Indonesia) dan bangsa Mongolia. Hal lainnya yang mempengaruhi adalah karena posisi strategis Makassar kala itu sehingga menjadi tempat persinggahan dan transit pedagang dari Eropa, Arab dan Mongol yang datang ke Indonesia untuk membeli rempah-rempah sekaligus membawa barang dagangan dari negeri mereka. Daerah kekuasaan Gowa-Tallo pada masa itu meliputi Sulawesi, Maluku bagian tengah dan tenggara, Nusa Tenggara sampai Filipina bagian selatan serta Kalimantan bagian timur. Benteng Ujung Pandang atau Fort Rotterdam disebut juga benteng Pannyua yang terdapat di Kota Makassar serta benteng Somba Opu di kabupaten Gowa adalah benteng peninggalan kerajaan Gowa-Tallo yang dibangun oleh Tunipa'risi Kallonna, Raja Gowa ke-9 (Anonimous, 2018a, Anonimous, 2018b). Disebut benteng Pannyua karena bentuknya menyerupai penyu yang menandakan simbol bahwa kerajaan Gowa-Tallo kuat di darat dan di laut, sedangkan benteng Somba Opu merupakan tempat tinggal Raja dan para bangsawan Gowa-Tallo. Benda-benda peninggalan sejarah kerajaan ini dan hal lainnya bisa dijumpai di Istana Balla Lompoa yang terletak di Sungguminasa, ibukota kabupaten Gowa. Dalam istana Balla Lompoa juga bisa disaksikan struktur atau silsilah keluarga Raja/bangsawan Gowa-Tallo mulai dari keturunan pertama kerajaan Gowa-Tallo yaitu Tumanurung dengan Karaeng Bajo sampai dengan Raja yang sekarang yaitu yang ke-37. Hal yang sama terlihat di istana Kesultanan Ternate (kedaton Ternate). Pajangan dan silsilah keturunan sultan dari yang pertama hingga ke-48.

Penduduk Kota Makassar saat ini sebagian besar terdiri dari Makassar, Bugis, Mandar, Toraja, etnis lain di nusantara serta keturunan China. Mereka umumnya berprofesi dibidang barang dan jasa, industry pengolahan hasil pertanian, perikanan dan kelautan serta bidang lainnya. Dengan penduduk yang sudah bervariasi tersebut diatas, mereka umumnya menggunakan bahasa Indonesia dialek Makassar dalam pergaulan sehari-hari. Bahasa Makassar, Bugis, Toraja dan Mandar hanya dipakai dilingkungan rumah. Penutur bahasa Makassar masih banyak dijumpai pada perkampungan yang didominasi oleh orang Makassar. 


\section{Daerah Galesong, Kabupaten Gowa dan Kabupaten Takalar}

Galesong adalah pusat angkatan laut Kerajaan Gowa-Tallo pada masa keemasannya di zaman Raja ke 15 dan 16 sebagaimana yang telah disebutkan diatas. Panglima Angkatan Laut Kerajaan Gowa-Tallo yang terkenal dan membantu Sultan Hasanuddin melawan Belanda adalah Laksamana Alimuddin, Karaeng Bontomarannu bersama-sama dengan Karaeng Galesong. Daerah ini sejak dulu dikenal sebagai daerah yang cukup subur menjadi penyublai ketersediaan pangan baik pada zaman dulu maupun sekarang di Kota Makassar dan sekitarnya. Hasil pertanian berupa padi, jagung, kacang-kacangan dan buah-buahan selain hasil perikanan dan kelautan.

Penduduk Galesong umumnya terdiri dari orang Makassar dan menggunakan bahasa Makassar dalam berkomunikasi sehari-hari. Daerah Galesong secara administrasi sebagian besar tergabung dalam Kabupaten Takalar, yaitu Kecamatan Galesong Utara, Galesong dan Galesong Selatan, sedangkan yang tergabung dalam Kabupaten Gowa adalah Kecamatan Bontonompo dan Bontonompo Selatan. Perkerjaan utama orang Galesong adalah bertani dan nelayan.

Nelayan yang banyak beroperasi di daerah ini adalah penangkap telur ikan terbang yang dinamakan Pakkaja. Daerah operasinya meliputi sekitar pantai ini sampai di perairan Papua dan Maluku bagian tenggara. Hasil tangkapan telur ikan terbang sebagian besar (75-80\%) disuplai dari Perairan Papua, 20\% dari Perairan Maluku bagian Tenggara (Dobu dan Tual) dan 10\% disuplai dari perairan setempat. Pemilik modal yang oleh orang Makassar menyebut dengan punggawa mempunyai kepemilikan dan membiayai biaya operasional alat tangkap. Mereka umumnya berdomisili di daerah ini.

\section{Bira, Tana Beru dan Kajang, Kabupaten Bulukumba}

Bira dan Tana Beru terletak di Kabupaten Bulukumba bagian timur. Penduduk kedua desa ini menggunakan bahasa Konjo, suatu sub bahasa dari Suku Makassar. Umumnya orang Konjo dan orang Makassar bisa saling memahami kalau mereka berkomunikasi. Mata pencaharian utama penduduk kawasan ini adalah melaut. Orang Tana Lemo dan Ara ahli dalam membuat dan merakit perahu dalam berbagai ukuran dan type. Berbagai jenis perahu pinisi, Lambo, Jolloro dan sampan dengan berbagai type dan ukuran mereka bisa buat, sedangkan orang Bira ahli didalam melayarkan perahu-perahu tersebut diatas. Sehingga ada istilah pasingkolona tu arayya, parapa'na tu tana lemoyya, passombalana tu Birayya (tukang peletak dasar pembuatan perahu orang Ara, tukang merakit perahu orang Tana Lemo dan tukang melayarkan perahu adalah orang Bira. Pusat pembuatan perahu terdapat dulunya di Bira dan sekarang berkembang di Tana Beru. Sementara kaum perempuan orang Bira mempunyai kebiasaan menenun kain sarung dengan berbagai motif dengan bahan dari benang sutera dan biasa.

Kajang adalah salah satu kecamatan dalam Kabupaten Bulukumba dan letaknya sama dengan diatas yaitu di bagian timur. Sebagaimana penduduk Kabupaten Bulukumba bagian timur pada umumnya mereka menggunakan bahasa Konjo dalam pergaulan sehari-hari. Secara adat penduduk Kajang terdiri atas Kajang Dalam dan Kajang Luar. Penduduk Kajang luar sudah beradaptasi dengan kehidupan masyarakat pada umumnya, sementara Kajang Dalam masih 


\section{TECHNO: Vol. 07 ( 01) Mei 2018}

berpegang pada aturan-aturan adat yang dalam bahasa Konjo disebut dengan Pappasang. Secara struktur lembaga adat, Ketua Adat disebut dengan Ammatoa dibantu oleh beberapa pembantunya secara adat dan bekerja sesuai dengan aturan-aturan adat. Struktur ini juga berdasarkan aturan-aturan adat dalam masyarakat Kajang Dalam.

Penduduk daerah Kajang sebagian besar berprofesi sebagai petani dan nelayan. Mereka umumnya mengolah lahan pertanian berupa sawah dan perkebunan. Hasilnya berupa padi, jagung, tanaman palawija, karet dan hasil perkebunan lainnya. Nelayan mengusahakan berbagai jenis alat tangkap diantaranya pancing dan purse seine (bahasa konjo : gae).

\section{KESIMPULAN}

Beberapa kesimpulan dan saran yang dapat diambil berdasarkan hasil dan pembahasan diatas adalah sebagai berikut :

1. Benteng Somba Opu adalah peninggalan sejarah Kerajaan Gowa-Tallo di Kabupaten Gowa dan Benteng Fort Rotterdam atau Ujung Pandang sering juga disebut benteng pannyua berada di Kota Makassar, sementara di Balla Lompoa masih bisa ditemui benda-benda peninggalan sejarah atau pusaka Kerajaan ini jaman dulu.

2. Galesong adalah daerah yang secara administrasi tergabung dalam Kabupaten Gowa dan Takalar, penduduknya bermata pencaharian petani dan nelayan dan menjadi salah satu penyuplai bahan pangan di Kota Makassar dari jaman dulu sampai sekarang serta menggunakan bahasa Makassar dalam berkomunikasi sehari-hari.

3. Penduduk Bira, Ara dan Tana Beru serta Kajang menggunakan Bahasa Konjo, sub bahasa dari Makassar dengan pekerjaan utama melaut dan membuat serta melayarkan perahu pada penduduk Bira, Ara dan Tana Lemo. Penduduk Kajang terdiri dari Kajang Dalam dan Luar dimana Kajang dalam masih mempertahankan aturan adat yang diketuai oleh Ammatoa dibantu oleh beberapa tetua adat dengan bekerja sesuai dengan aturan adat, sementara Kajang Luar sudah beradaptasi dengan perubahan. Pekerjaan mereka umumnya bertani dan menjadi nelayan.

\section{SARAN}

Diperlukan penelitian-penelitian lanjutan secara spesifik, hubungan antara sosial ekonomi dengan bidang pertanian, perikanan dan kelautan, hukum, politik dan budaya agar dapat mengungkap secara jelas gambaran masyarakat di pesisir Sulawesi Selatan.

\section{UCAPAN TERIMA KASIH}

Penulis mengucapkan terima kasih kepada Prof. Nagatsu Kazufumi dari Faculty of Sociology, Tokyo University-Jepang atas nasehat, petunjuk dan dorongannya selama mengikuti kegiatan fieldwork sampai penyusunan paper ini. Demikian pula penulis mengucapkan ucapan terima kasih kepada Prof. Dr. Dadang Ahmad Suriamiharja, M.Sc, Dr. Ir. Dorotea Agnes Rampisela, M.Sc dan Dr. Andi Amri, S.Pi, M.Sc dari Universitas Hasanuddin, Makassar, Sulawesi Selatan yang telah mengorganisir kegiatan ini dengan peneliti dari beberapa universitas/lembaga di 
Jepang sehingga kegiatan penelitian ini dapat terlaksana. Selain itu penulis mengucapkan terima kasih kepada masyarakat di daerah Galesong, Kabupaten Gowa dan Takalar serta di daerah Tanah Beru, Bira dan Kajang, Kabupaten Bulukumba, Provinsi Sulawesi Selatan sehubungan dengan sharingnya terhadap gambaran sosial ekonomi masyarakat dan lingkungannya.

\section{DAFTAR PUSTAKA}

Anonimous. 2018a. Fort Somba Opu Wiki-Visually.

https://wikivisually.com/wiki/Fort_Somba_Opu. Diakses 22 Januari 2018.

b Fort Rotterdam - Wikipedia.

https://en.wikipedia.org/wiki/Fort_Rotterdam. Diakses 22 januari 2018.

Nuitja, I.N.S. 2010. Manajemen Sumberdaya Perikanan. Penerbit IPB Press. Bogor. 